\title{
THE INTERNATIONAL LAW OF COMMODITY AGREEMENTS
}

\author{
HERMAN WALKER*
}

Since intergovernmental commodity agreements are agreements between governments about internationally traded commodities and are designed to affect the flow of commodities in international commerce, they may be regarded as a form of trade agreement. ${ }^{1}$ Therefore, it is from the standpoint of relationship with the legal standards applicable to trade agreements generally that the subject will be examined here.

\section{The General Framework}

In the large sense, any trade agreement is a commodity agreement, because trade agreements deal with the tangible things that move in commerce and commit governments as concerns the governmental measures (e.g., rates of duty, quotas) impinging on importation and exportation generally. As a generic term to denote the subject-matter of trade agreements, "commodities" is used interchangeably with "articles," "goods," and "products." The former, however, has also come to be used often to refer to a segment of the whole, with or without adjectivals such as "basic" commodity or "primary" commodity or "bulk" commodity, to mean fungible goods of a raw material or semi-processed sort. Hence "commodity agreement" as a special class. Even so, "commodities" limitatively defined can be, and normally are, part and parcel of trade agreements concerned with the generality of trade. As such, they can be, and are, included on an equal footing with other goods in schedules of agreed tariff rates and, unless expressly set apart, subjected alike to the common rules regarding most-favored-nation treatment, internal taxation, quantitative restrictions, rates-of-exchange, methods of valuation, and the rest.

There now exists a widely-accepted master agreement dealing with trade: the General Agreement on Tariffs and Trade (the GATT, or the "General Agreement") which, in the course of thirty-six articles, nine annexes, and several other ancillary instruments, sets forth a comprehensive body of international rules governing trade policies and practices. ${ }^{2}$ In general, this body of rules covers all the foreign commerce

*A.B. I931, M.A. I933, Ph.D. I937, Duke University. Visiting Professor of Political Science, Duke University, 1962-63. State Department and U.S. Foreign Service Officer, 1946-1962; Vice-Chairman, U.S. Delegation, GATT Tarif Negotiations, Geneva, 1960-1962. Contributor to legal and other periodicals.

'They can also be regarded as a "species of cartel" (as in George W. Stocking \& MYron W. WATrins, Cartels or CoMpetition 302 and passim (1948)), inasmuch as they "restrain competition" and "limit access to markets" (wording of introductory provision on restrictive business practices, HavaNA Charter art. 46). They are on their face distinguishable from cartels, however, by the circumstance that they are entered into by governments rather than by private (or "public commercial") enterprises, and as a matter of public international relations rather than of "business practices."

2 This agreement is in force, for the United States, by virtue of the Protocol of Provisional Application 
of the fifty contracting parties thereto (accounting together for about five-sixths of "free-world" commerce), without distinction between kinds of goods." Under the aegis of these rules, tens of thousands of tariff positions, in the variegated customs structures of the members, have been subjected to particular rate-of-duty commitments in the course of the five general rounds of tariff-reduction negotiations held in GATT conferences from 1947 to date, including commodities for which "intergovernmental commodity agreements" have been proposed or reached. ${ }^{4}$

The master rules embodied in the General Agreement are framed in light of a design to stimulate international trade and to promote the efficient international distribution of production by diminishing and removing the interferences that prevent the play of market forces from determining the volume and direction of exports and imports. In the ideal, these rules aim for a competitive world market. They thus seek to abolish discrimination among sources of supply, whether in the form of preferential duties, closed "bilateral" deals, quotas, or otherwise; to dismantle administrative controls and other managerial devices calculated to substitute tradedistorting governmental decision for trader discretion; and to establish the fixed customs duty as the sole regulator-at-law of the movement of goods across national boundaries, duty-rates in turn to be subject to periodic negotiation with a view to their progressive lowering. The drafting of these rules, in all their ramifications and compromises, leaves the ideal short of realization in a number of respects; but the qualifications and exceptions are for the most part framed in guarded language designed to curb abuse and to minimize infraction of the scheme's symmetry.

The relatively competitive model of a world market envisioned by this body of rules is deemed by many interested parties to provide an insufficiently orderly, just, and efficacious framework for the trade in, and the underlying production of, certain commodities. Such commodities are those be-dogged by special problems discussed elsewhere in this issue, the tolerable solution of which is thought to require some degree of planning and concerted direction on a multi-national basis. It is for the establishment of a degree of managed trade-economy for such commodities that "intergovernmental commodity agreements" are designed. 5 The "intergovern-

done at Geneva, Oct. 30, 1947, T.I.A.S. No. 1700. A convenient print of the text, as currently revised, is The General agreement on Tariffs and Trade, U.S. Dep't of State Pub. No. 7182 (ig6i).

${ }^{3}$ Except for certain ones expressly excluded from the scope of the agreement, notably the monetary metals (gold and silver), munitions, fissionable materials, archaeological treasures, prison-made goods. GATT art. XX(c), (e), (f), and art. XXI(b), (i) and (ii); and a special arrangement for Cinematograph Films, art. IV.

- See, for illustrations, the schedule of tariff concessions accorded by the European Economic Community (EEC) at the I960-6I tariff conference, Geneva, consolidated GATT schedule XL: Cacao (position 18.01), cotton textiles (positions 55.06, 55.07, 55.09, 6r.01-6r-05). Pre-EEC commitments on wheat (Brussels nomenclature position 10.0I) were variously in force for all the member countries by virtue of regotiations held in the period 1947-1951. The United States, for example, has made commitments on the sugar duty (para. 501, U.S. tariff) and olive oil (para. 53).

This statement applies to the particular form of commodity agreement known as a commodity "control" agreement (Havana Charter ch. VI, art. 6r, and sec. C (1948). There are, in addition, instruments called commodity agreements that are of a less ambitious scope, not involving controls; but these, as they do not affect the GATT's master rules for trade in general, are not dealt with in the present paper. 
mental commodity agreement," as a term of art, accordingly denotes a multilateral agreement that segregates a given commodity for special handling under special rules and arrangements going beyond and departing from those governing the generality of goods. There is no prototype of commodity agreement that serves as a model; each of the four or five so far successfully negotiated ${ }^{6}$ during the GATT era (wheat, tin, sugar, and coffee, with the possible fifth being that on cotton textiles), differs from the other, each having been tailor-made to fit varying individual circumstances. But certain key elements, one or more of which are found in some form in every "commodity control" agreement, give them their distinctiveness and raise potential questions of compatibility with the master rules set forth in the GATT.

These elements are: (I) the buffer stock device (e.g., tin agreement). This may be noted and passed over briefly. In and of itself, without more, a buffer-stock operation, involving in practice merely an open-market intervention taking the form of a timely buying up and selling of stocks in order to hold price fluctuations within a minimum-maximum range, ${ }^{7}$ would not on its face involve any readily evident conflict with any operative provision of the General Agreement. ${ }^{8}$ Prima facie incompatibilities emerge, rather, when the agreement provides for:

(2) quantitative limits on imports and/or exports,

(3) quantitative allocations as among suppliers and takers,

accompanied by restraints upon the freedom of importers to procure, or exporters to sell, outside these quantitative prescriptions. Such features are conspicuously inconsistent with articles XI and XIII of GATT, and perhaps with article I. There would also occur an inconsistency with article $I$ and possibly article II as well, if (as

"Non-control, essentially promotional, agreements are not counted here: e.g., "constitution" of the International Rice Commission, as amended, I960, T.I.A.S. No. 5204, and the olive-oil agreement (text in United Nations Conference on Olive Oil 1955, U.N. Doc. No. E/conf. 19/5 (N.Y. 1956)) which especially is concerned with standards, labeling, and indication-of-origin practices. Also excluded are agreements of the sort mentioned in the exceptions article of the Charter (art. 70): e.g., those for sanitary purposes (such as the draft opium convention of 1950 , which, however, followed Charter criteria), conservation (such as whaling and sealing conventions), or equitable distribution of goods in short supply (essentially a transient war and war-aftermath phenomenon). Finally, there is omitted, as of no current pertinence, the International Tea Agreement of 1950, which expired in March 1955; this, it may be said, was a producer agreement among India, Pakistan, Ceylon, and Indonesia, which, although a "control" agreement in nature, failed to provide equal representation for consuming countries (text in Review of International Commodity Problems 1950, at $54-57$ (U.N. Doc. No. E/1907) (1951). For a com. pilation of pre-war and early wartime agreements, sce International Labor Organization, Intengovernmental Commodity Control Agreements (i943).

"Such an intervention, as it presumably involves a "regulation of prices" within the intendment of para. 2 (b), art. $6 \mathrm{I}$ of the Havana Charter, places an agreement relying on this device within the definition of a "control" agreemcnt. Clatr Wilcox, A Charter gor World Trade IIg (I949).

${ }^{8}$ Conceivably, relevant GATT provisions would be art. XVI, on the argument that the buffer-stock is a form of indirect export subsidy, and art. XVII, on the argument that it is a form of state trading. But for a complaint to be sustainable under art. XVI, it would have to be shown that the subsidy serves to "increase exports" from the contracting parties operating the buffer stock at the cost of "scrious prejudice to the interests" of a third party, a showing difficult to make in the premises. As for art. XVII, it would have to be shown that the operation practiced discrimination among exporting countries in its purchases, or among importing countries in its sales, a policy course that would violate the inherent aim and nature of a buffer stock. 
an enforcement measure) penalty duties were assessed upon importations from or exportations to non-cooperators.

II

The General Agreement on Tariffs and Trade

The pertinent GATT provisions, that pose questions of compatibility, provide as follows:

Article XI. General Elimination of Quantitative Restrictions.

r. No prohibitions or restrictions ... whether made effective through quotas, import or export licenses or other measures, shall be instituted or maintained by any contracting party on the importation of any product of the territory of any other contracting party or on the exportation or sale for export of any product destined for the territory of any other contracting party.

Article XIII. Non-discriminatory Administration of Quantitative Restrictions.

r. No prohibition or restriction shall be applied by any contracting party on the importation of any product of the territory of any other contracting party or on the exportation of any product destined for the territory of any other contracting party, unless the importation of the like product of all third countries or the exportation of the like product to all third countries is similarly prohibited or restricted. 9

Article I. General Most-Favored-Nation Treatment.

x. With respect to customs duties and charges of any kind imposed on or in connection with importation or exportation ... any advantage, favour, privilege or immunity granted by any contracting party to any product originating in or destined for any other country shall be accorded immediately and unconditionally to the like product originating in or destined for all other contracting parties. ${ }^{10}$

In as much as the obligations imposed by these provisions are consensual, the contracting parties to GATT are free, if they wish, to waive them by agreement. They can do so formally in "exceptional circumstances" by a two-thirds vote (article twenty-five, paragraph five), acting "jointly" as CONTRACTING PARTIES, ${ }^{11}$ a procedure that tends to be utilized only grudgingly. ${ }^{12}$ Even without such

'Succeding paragraphs prescribe acceptable methods for realizing the precept of "similarly restricted": e.g., individual quotas "approaching as closely as possible the shares which the various contracting parties might be expected to obtain in the absence of such restrictions" (para. 2). The logic of an article XIII, which presupposes the existence of the very restrictions solemnly outlawed by article XI, is that certain exceptions to the sweeping rule of art. XI are recognized: notably, inter alia, restrictions necessary to safeguard a country's balance-of-payments (art. XII) or necessary to the orderly administration of a domestic crop-control program (art. XI, para. 2(c)).

${ }^{10}$ The fourth GATT article alluded to, article II, provides for fixed tariff commitments, reached by negotiation and incorporated into the Schedules annexed to the General Agreement: "bindings" of Iates at fixed levels that a contracting party is obligated not to exceed.

${ }^{2 x}$ This term in all capital letters is used to signify the collectivity of the contracting parties, acting as a group for decisional purposes and management of the GATT's affairs. This euphemism has been necessitated by the fact that GATT was created without the formal status of an "organization," but in the form merely of an international agreement functioning through periodic conferences. Originally, this improvisation was a stop-gap to tide over until the ITO Charter should come into force. The Charter 
formal action, any special arrangement would in effect be removed implicitly from the operation of the master rules as between the parties participating in it and, further, to the extent that non-participants assented. Such assent could, as a practical matter, be given by failure to object; the GATT is not equipped with a policing organ, but rather does nurture an emphasis on problem-solving by the process of cooperation and accommodation. Issue would be drawn, however, if there were objecting non-participants who considered themselves aggrieved by the impact of a commodity agreement and chose to interpose complaint. To cover this eventuality, the General Agreement, in response to a widespread feeling that commodity agreements when desired and needed should be facilitated and that their negotiators should be allowed a considerable latitude to search out viable terms, contains a special proviso regarding the permissibility of such agreements.

This proviso, article $\mathrm{XX}(\mathrm{h})$, is in the form of a reservation. It provides that nothing in the General Agreement shall prevent any contracting party from carrying out the obligations of "any intergovernmental commodity agreement" that meets certain criteria, subject to the condition that the measures of implementation "are not applied in a manner which would constitute a means of arbitrary or unjustifiable discrimination between countries where the same conditions prevail, or a disguised restriction on international trade." If the commodity agreement, as carried out, falls within the four corners of this reservation, it is by definition immune from challenge as to legality. This, however, does not necessarily mean that the GATT leaves aggrieved members ${ }^{13}$ without all recourse. For while dissenters would be barred from alleging an illegal breach of articles I, II, XI, XIII, or XVI or XVII, it would be open to them to marshal a complaint under article XXII and article XXIII, the independent force and effectiveness of which, notwithstanding the article XX reservation, is emphasized by their being carried in sequence at a point after that article., ${ }^{14}$ The burden of proof devolving upon complainant might be substantial. But the right of discharging this burden, by any contracting party disposed to try, is acknowledged. The fact that the GATT sympathetically recognizes the legitimacy of commodity agreements does not mean that the presumption in favor of the accept-

having proved abortive, an effort subsequently was made to set up formally an organization to administer GAT'T through the creation of an Organization for Trade Cooperation by special agreement opened for acceptance on March I0, I955; for text, see GATT, Bastc INSTRUMENTs AND SELECTED Documents, volume I, revised; for discussion, see Bronz, An International Trade Organization: The Second Attempt, 69 HARv. L. REv. 440 (1956). But this effort also failed, owing largely to opposition in the United States Congress. For the United States, the GATT is in effect as an Executive Agreement, by virtue of the President's authority to enter into trade agreements under the provisions of the Trade Agreements Act as successively extended or replaced since its inception in 1934 .

${ }^{12} \mathrm{~A}$ cumulative listing of waivers granted, 1947-196r, may be found in GATT, BAstc INsTrumeNTs AND SELECTED Doctoments $284-87$ (roth Supp. I962) [hercinafter cited as BISD].

${ }^{13}$ The term "members" here is used for convenience to denote individual "contracting parties" to the GATT, the latter term only being the technically correct one in as much as the role of membership implies that there is an "organization" to be "member" of.

14 For reference to cases on the right of recourse and remedy, under the articles, for damage resulting from lawful action, see Hollis, Dispute Settlement Under the General Agreement on Tariffs and Trade, in Martin Domke (ED.), International Trade Arbitration 77-84 (1958). 
ability of a commodity agreement, even when meeting the prescribed criteria, is conclusive upon all GAT'T members.

Article XXII provides for the right to make representations, to consult, to receive "sympathetic consideration," and to enjoy the good offices of the CONTRACTING PARTIES "with respect to any matter affecting the operation of this [the GATT] Agreement." Article XXIII takes the recourse procedure a step further, by providing that

If any contracting party should consider that any benefit accruing to it directly or indirectly under this Agreement is being nullified or impaired or that the attainment of any objective of the Agreement is being impeded as the result of ... (b) the application by another contracting party of any measure, whether or not it conflicts with the provisions of this Agreement, or (c) the existence of any other situation (emphasis added)

such aggrieved party is entitled to petition for relief, first to the offender or offenders and, failing satisfaction there, to the CONTRACTING PARTIES. The latter are directed to investigate promptly, and are empowered to pronounce rulings regarding questions in issue and make recommendations for such remedial measures as might appear to be appropriate; in extremis the aggrieved party may be authorized to retaliate by way of righting an upset balance. The lines of allegation that might be advanced in prosecuting the recourse thus afforded for equitable relief, from a lawful but harmful act, can be illustrated by the following examples:

Case I. A non-participating exporter member has, for value given in one of the reciprocal tariff negotiating conferences, secured from a participating importer member, directly or indirectly, ${ }^{15}$ a commitment on the rate of import duty applicable to the commodity in question. But the importing country, in obedience to the commodity agreement, refuses to allow importations from complainant at the contractual duty-rate in the amounts complainant is ready, willing, and able to supply. It does so either by outright prohibition of all over a quota assigned to complainant without its consent, or by imposing a penalty charge on over-quota consignments. To point up the case, hypothesize as complainant an efficient, rising producer, ${ }^{\mathbf{1 6}}$ which counts on earnings from its exports of the commodity in question (particularly in complainee's market) to balance its external trade accounts, and which has been scrupulously fulfilling all tariff commitments it has made benefiting the trade of complainee. Complainant could plausibly contend that a "benefit accruing to it . . . is being nullified or impaired," within the evident purview of article XXIII: a benefit expected by virtue of article II and article XI.

15 The word "directly" connotes a concession granted to the beneficiary thereof in its name (here, complainant), while "indirectly" refers to a concession granted to some third country which accrues to others (including, here, complainant) by virtue of the most-favored-nation treatment principle. The multilateralization of all tariff concessions (art. II, para. I-a) is one of the quid pro quo's of the GATT, for each and all of its members.

${ }^{10}$ This would be precisely the kind of country most apt to decline to participate in a commodity agreement, out of dissatisfaction with having to accept limitations on the exploitation of its own export potentialities in order to shore up its less efficient competitors. 
Case 2. Suppose the same facts, ${ }^{17}$ with the difference that complainee has not contracted any commitment regarding the rate of duty applicable to the commodity in question, and thus remains free under GATT to increase it (subject, of course, to the requirement of article I regarding non-discriminatory application of whatever duty is assessed). Here, the complainant would presumably have to rely on arguments colored by value judgment and choice among conflicting internationally enunciated policy objectives. It is assumed that the commodity agreement has provided what at least the negotiators thereof consider an "equitable treatment" (i.e., an equitable quota) ${ }^{18}$ for the exports of the complainant, as contemplated in the criteria approved by the above-cited article $\mathrm{XX}(\mathrm{h})$ reservation; ${ }^{10}$ and what they also consider avoidance of any "arbitrary or unjustifiable discrimination," or of any "disguised restriction" in international trade, as also required by the language of the same reservation. The question would remain whether the commodity-control actions of defendant none the less "impeded" the "attainment of any [GATT] objective," within the meaning of article XXIII-not objectives generally, but any objective.

As listed in the preamble, the objectives of the General Agreement are: (i) "raising standards of living," (ii) "ensuring full employment," (iii) "a large and steadily growing volume of real income and effective demand," (iv) "developing the full use of the resources of the world," and (v) "expanding the production and exchange of goods."20 Prima facie, the unwanted restrictions on complainant's export outlets, and their consequent adverse impact on the producers and workers occupied with the commodity, run counter to every one of these objectives in so far as complainant's economy is concerned, and-in several particulars-counter to them on a near-term world basis. Moreover, immediately succeeding the recitation of objectives, and corollary to them, there are set forth the approved techniques for moving toward the foregoing objectives: namely, the "substantial reduction of . . . barriers to trade" and the "elimination of discriminatory treatment in international commerce." So far as this declaratory-of-objective wording is concerned, it would be immaterial that the trade barrier erected by a commodity agreement is not "disguised," or that the discrimination is not "arbitrary or unjustifiable." The wording is unqualified.

${ }^{17}$ A Case 3 would be the converse situation. An importing country prevented by export quotas from obtaining all it wanted of the commodity, at commercial prices, for the use and bencfit of its people.

${ }^{18}$ As stipulated in art. 60, para. I (c) of the Havana Charter, incorporated by reference via interpretative note "Ad Article XX" in Annex I of the General Agreement.

10 A contest over whether the treatment granted actually was "inequitable" within the meaning of the stipulation cited in the foregoing footnote would, of course, push the controversy from the plane of harm-without-illegality to that of lawfulness itself. The difficulty of determining with any degree of objectivity just what does constitute equitable treatment, so as to pose an issue of legality, is compounded by the fact that art. 60, para. I(c) further recites, ". . . due consideration is being given in each case to policies adopted by non-participants in relation to obligations assumed and advantages conferred under the [commodity] agreement." Equity thus becomes colored by the subjective cvaluations of the participants, one of whose aims is to safeguard against frustration of the agreement by "free-riding" nonparticipants.

${ }^{20}$ In a long-pending revision of the General Agreement, the recitation is to be transposed to article I, entitied "Objectives," and a sixth element added, namely, "promoting the progressive development of the economies of all the contracting parties." 
Counterposed would be such considerations as the following. In so far as alleged "discrimination" is concerned, country quotas do not of themselves constitute discrimination, so long as the limits established are prorated among the interested countries according to the formula typically employed in the absence of individual agreement: that is, allocation on the basis of a "previous representative period ... due account being taken of any special factors which may have affected or may be affecting the trade in the product."20a For the rest, the statement of GATT "objectives" is an introductory sketch that should be read in a global, long-range and imprecise sense; being preambulary, they rest, for their more detailed and explicit definition, on the operative provisions of the body of the Agreement; and article XXIX, paragraph $r$, in effect substitutes special commodity-agreement objectives for GATT preamble objectives in the particular case of a commodity agreement, ${ }^{21}$ an interpretation morally strengthened by repeated resolutions of the United Nations Economic and Social Council supporting the commodity-agreement idea. ${ }^{22}$ Relevant commodity agreement objectives, which would thus prevail, include: "(a) to prevent or alleviate the serious economic difficulties which may arise when adjustments between production and consumption cannot be effected by normal market forces alone as rapidly as the circumstances require; (b) to provide . . . a framework for the consideration and development of measures which have as their purpose economic adjustments ...; (c) to prevent or moderate pronounced fluctuations in the price of a primary commodity. ..."22a

Just where these cross-currents of interpretative argument would ultimately lead, in terms of authoritative decision, yet remains to be seen. So far, none of the actually consummated commodity agreements has been contested in the CONTRACTING PARTIES. One reason is that, as a practical matter, these agreements have come into being after long multilateral deliberation and tedious negotiation, with consequent reconciliation of conflicting interests and achievement of a broad consensus of explicit and implicit acceptance or tolerance. In general, the habit of cooperation through frequent congregations fostered by the GATT, with a view to proceeding on the basis of mutual understanding, is conducive to such a result. In particular, the framework of standards and procedures elaborated in chapter VI of the Havana Charter for the formation of commodity agreements, by serving as an acknowledged

202 GATT, art. 13, para. 2(d).

${ }^{21}$ Article XXIX, para. I provides that "The contracting parties undertake to observe to the fullest extent of their executive authority the general principles of chapters I to VI . . . of the Havana Charter pending their acceptance of it ...." Whether the Charter is in fact still "pending" is questionable; and this passage will be dropped (as part of a tidying-up of references to the defunct Charter) if and when the revisions alluded to in note 20 , supra, come into effect. But, if so, the argument could still be made on the basis of article $\mathrm{XX}(\mathrm{h})$, with its interpretative note, as reinforced by the addition of the sixth element to the "Objectives" quoted in note 20 , supra.

${ }^{22}$ E.g., those cited infra at notes 25 and 29; the I954 resolution establishing a permanent advisory Commission on International Commodity Trade (UN ECOSOC REs. No. 5 I2A (xvii), adopted April 30, I954, and E/Rrsolumon (xviii)/28-D, adopted Aug. 5, 1954).

22* HAVANA Charter art. 57. 
guide to the GAT'T membership, also contributes very considerably to that result. Attention may now be turned to that chapter.

III

\section{The Havana Charter}

The Havana Charter for an International Trade Organization, of which chapter VI is part, was consummated in March 1948 by the United Nations Conference on Trade and Employment at its convocation in Havana (hence, "Havana Charter" for short, or "ITO Charter"). ${ }^{23}$ It is a laboriously prepared and ambitious document of 106 articles (plus annexes), including chapters on Employment and Economic Activity, Economic Development and Reconstruction, Commercial Policy, Restrictive Business Practices, and Intergovernmental Commodity Agreements, in addition to its organizational and procedural provisions. It proposed a common denominator for dealing comprehensively in an orderly way with international commerce in the setting of a diversity of nation-state interests. Thus it was hardly fortuitous that it should contain a chapter on intergovernmental commodity agreements immediately following one on restrictive business practices, the one curbing collusive trade restraints on the part of commercial enterprises and the other allowing (under safeguards) intergovernmental regulation of the commodity trade. ${ }^{24}$

While the final text was still in preparation, and in order to signal approval of the proposed commodity-agreement regime pending the Charter's outcome, the United Nations Economic and Social Council (ECOSOC), on March 28, r947, passed a resolution incorporating, among other things, the following recommendation $:^{25}$

... that, pending the establishment of the International Trade Organization, Members of the United Nations adopt as a general guide ... the principles laid down in chapter VII as a whole, i.e., the chapter on inter-governmental arrangements ... although recognizing that discussions in future sessions . . . may result in modifications. . . .

${ }^{23}$ The noncommittal Final Act authenticating the text was signed by representatives of 53 countries, comprising most of the then membership of the United Nations, with the conspicuous exception of the U.S.S.R.

${ }^{24}$ The charge that thereby the Charter was condoning restrictive practices by governments, of the very kind forbidden to private enterprise, was one ground for vigorous opposition to the Charter on the part of the National Foreign Trade Council, broadly representative of U.S. business firms having forcign trade and investment interests. Position of the National Foreign Trade Council With Respect to the Havana Charter for an International Trade Organization, submitted to the House Committee on Foreign Affairs at Hearings on H.R. I. Res. 236, Membership and Participation by the U.S. in the I.T.O., Before the House Comm. on Foreign Affairs, 81st Cong., 2d Sess. 8, 112-20 (1950). The National Association of Manufacturers made a like argument. See Bidwell \& Diebold, The United States and the International Trade Organization, InT'L Conc. PAMphLET No. 449, at $2 \times 8$ (r949).

${ }^{25}$ Resolution No. 30(IV), U.N. Doc. No. E/403. The resolution goes on to request the Secretary General to set up an Interim Coordinating Committee for International Commodity Arrangements, consisting of a Chairman representing the Preparatory Committee of the United Nations Trade and Employ. ment Conference, a member nominated by the FAO, and a third person representing non-agricultural primary commodities. 
What began as chapter VII in the then extant $\mathrm{draft}^{26}$ became ultimately chapter VI, owing to a rearrangement of no material significance. ${ }^{27}$ The Havana Charter, in fact, proved abortive; it never entered into force. ${ }^{28}$ Accordingly, the ECOSOC at its thirteenth session passed a duly revised repeater resolution in which $\mathrm{it}^{29}$

(1) ... reaffirms ... Council resolution 30 (iv) of 28 March 1947 ; (2) recommends that the Members of the UN continue to accept the principles of Chapter VI . . . as a general guide ... ; (3) requests the Secretary-General to reconstitute the Interim Co-ordinating Committee for International Commodity Arrangements so that it shall consist of a Chairman nominated by the Contracting Parties to the GATT. . . .

The GAT'T was fashioned in the course of the same preparatory work as an expedient to permit interested countries, pending the Charter's conclusion, to proceed immediately with carrying forward the Charter's more strictly "trade" provisions, that is, its chapter on Commercial Policy. In addition, the GATT picked up the purport of chapter VI by the technique of a summary reservation referring to the ECOSOC resolution of March I947, as mentioned above. ${ }^{30}$ This reference, as it now stands, contains a technical flaw, in that the authoritative current ECOSOC resolution is dated $195 \mathrm{I}$ and, inter alia, corrects the chapter numeration; but this flaw is not, so far as available evidence indicates, considered to be consequential. ${ }^{31}$ Thus the design of chapter VI is projected into the international legal system, even though its host document (the Havana Charter) never itself came into legal force and effect.

The GATT exception for commodity agreements (and behind it, the ECOSOC. resolution) speaks imprecisely in terms of "principles" and thus leaves latitude for interpretation. Moreover, the fact that it occurs in GATT as part of a larger

${ }^{20}$ The first (or "London draft") of three successive versions emanating from the Preparatory Committee of the United Nations Conference on Trade and Employment over the period October I946-August 1947, intervening between the launching of the U.S. initiative for the Charter and its technical completion: at Havana. The other two such preparatory versions are known as the "New York" and "Geneva" drafts, respectively. U.N. Doc. Nos. E/PC/T33, E/PC/T/34/rev. I, and E/PC/T/x86.

${ }^{27}$ This rearrangement involved the transposition of the subject matter of original chapter II ("member-. ship") to a later chapter.

${ }^{28}$ Perhaps the crucial factor was the hostility of the United States Congress; other countries tended. to consider it pointless to proceed unless and until the United States acted favorably. For a summary account, see Williale Diebold, Jr., The ENd of the I.T.O. (Princeton Essays in Internationate. Finsnce, No. 16) (1952); also see Bronz, supra note II.

${ }^{20}$ Resolution 373 (XIII), Sept. 13 , I95I. It will be noted that the GATT is now attributed the role of nominator of the chairman of the reconstituted committee.

${ }^{30}$ The wording of the original GATT (art. XX, para. I-h) related simply to measures "undertaken in pursuance of obligations under intergovernmental commodity agreements, conforming to the principles. approved by the Economic and Social Council of the United Nations in its Resolution of March 28, 1947...."

${ }^{21} \mathrm{~A}$ revision made in 1955 and now in force restated the body of clause (h) in broadened language: "... undertaken in pursuance of obligations under any intergovernmental commodity agreement which conforms to criteria submitted to the Contracting Parties and not disapproved by them or which is itself so submitted and not so disapproved." The reference to the ECOSOC resolution of 1947 was coterminously transposed to the interpretative notes (Annex I), by way of specifying that any agreement conforming thereto was predetermined to be in compliance with art. XX(h). The failure to update the referenceto 2951 was apparently a mere oversight; in any event, the "principles" approved by the ECOSOC in I947 remained essentially those approved in I95r. 
reservation which allows agreements not conforming with such principles, further dilutes the character of chapter VI as a rule of law. ${ }^{32}$ But the chapter has none the less acquired considerable authority as a guide to be followed and heeded, as will be seen below, when the extent to which it has been adhered to in the agreements actually negotiated during its life-span is examined.

Chapter VI addresses itself to "principles," by name, in articles 60 and 63 , respectively entitled "General Principles Governing Commodity Agreements" and "Additional Principles Governing Commodity Control Agreements." These articles together, as regards "control" agreements, provide for: (a) opportunity for nondiscriminatory participation by all Members of the Organization; (b) the possibility of non-Member participation, on a like basis; (c) as a corollary, negotiation for any agreement to be held in a duly-convoked and thoroughly prepared conference, to which all substantially interested countries have been invited; (d) the creation, in each case, of a governing "Commodity Council" in which voting strength is equally shared by the exporting and importing countries, as groups; (e) equitable treatment to non-participants; (f) assurances of the availability of adequate supplies of the commodity at prices fair to both producer and consumer; (g) "appropriate provision" for "increasing opportunities" that demand can be satisfied from "the most effective and economic" sources of production, "due regard being had to the need for preventing serious economic and social dislocation and to the position of producing areas suffering from abnormal disabilities"; (h) adoption of such programs of internal economic adjustment as might be deemed "adequate" and "practicable" in the direction of "solution of the commodity problem involved"; and (i) full publicity. Still further guidelines are afforded by other articles, entitled otherwise than "principles," to wit: (j) an initial duration of not exceeding five years (article 65, paragraph $\mathrm{I}$ ), for any given agreement; $(\mathrm{k})$ a dispute-settlement procedure, in first instance the Commodity Council, with recourse then to the Organization (article 66); and (1) a definition of the circumstances justifying an agreement, through a finding as stipulated by article 62 in light of criteria prescribed there and in articles 55 and 56 .

These dozen heads comprise a rather impressive array of safeguards calculated to insure the bona fides of each commodity control agreement. Some of them depend on value judgments for which there are no objective tests: (e) through (h) and, to a degree, (l). ${ }^{33}$ Others are more definite. In examining the extent to which the agreements so far concluded observe these criteria, or appear to endeavor to heed them as well as might be, it will be useful to divide the agreements into two groups: first, those dealing with primary commodities; ${ }^{34}$ and second, the cotton textile

\footnotetext{
${ }^{32}$ The ECOSOC resolution as such, and apart from the status given it as part of the law of the GATT, of course, has no mandatory force. But see infra at note 45 as to the subjection of particular commodity agreements, by their own terms, to principles approved by ECOSOC.

${ }^{38}$ It is in these heads, particularly, that are to be found the "escapes and weaknesses" of the chapter, which could conceivably prove fatal to the realization of its hopes, unless countries show vigilance and good faith in following its spirit. See, e.g., Stocking \& WATKuNs, op. cit. supra note r, at 449.

st International Sugar Agreement of 1958, T.I.A.S. No. 4389; International Wheat Agreement, 1962,
} 
arrangement. Further, they may be arrayed roughly in ascending order of discernible compliance.

\section{IV}

\section{Primaray Commodity Agreements}

As concerns the Wheat, Sugar, Coffee, and Tin Agreements, it is difficult to assess how well any of them meet the directive set forth in $(g)$, except to note that the buffer-stock feature of the Tin Agreement inherently, through open-market purchases and sales, puts some emphasis on the play of commercial forces, within the stipulated price range; ${ }^{35}$ and that the Wheat Agreement also affords room for advantaging the more efficient through leaving importers uncommitted regarding a portion (often, a substantial one) of their purchases. ${ }^{36}$ These four agreements again do not, in their preambles and recitations of objectives, evince overt cognizance of the purport of either $(\mathrm{g})$ or $(\mathrm{h})$, except for the following allusions: "To provide a framework for the consideration of measures to promote the progessively more economic production of tin, while protecting deposits of tin from unnecessary waste or premature exhaustion. ...." (Tin, article I-d); “. . . bring about long-term equilibrium between production and consumption" (Coffee, article I, paragraph $\mathrm{I}$ ).

Their caution or lack of forcefulness on this score, of course, testifies to the source of much of the skepticism had by critics regarding the utility of commodity agreements as instruments of an efficient trade policy; ${ }^{37}$ but that the Chapter itself, given its vague wording, can be said to be a clarion call to do much better is doubtful. The avowed aim of the several agreements, in general, appears to center on the notion of stabilization and income support in the framework of "equitable" prices,

T.I.A.S. No. 5115; Second International Tin Agreement (text in United Nations Tin Conference, r96o: Summary of Proceedings (U.N. Doc. No. E/CoNF.32/5, at 25-42); International Coffee Agreement, I962, Sex. Doc. Execurrve H. 87th Cong., 2d Sess., Oct. 4, 1962. All replaced earlier agreements, those relative to the first three named not generally having features materially different from the current versions, for purposes of the present discussion. In the case of the last named, the predecessor instrument was a "shortterm" year-to-year producer agreement that did not purport to follow the criteria of chapter VI, having been conceived as merely a temporary stop-gap to serve until an acceptable long-term agreement could be negotiated, as asserted in its preamble. Final Act of the Negotiations for the Conclusion of an International Coffee Agreement, signed at Washington, September 24, 1959; effective October I, 1959, and successively extended on its anniversary date I960, r961, and I962 (English text courtesy of SecretaryGeneral of the Coffee Study Group, Washington, D.C.).

${ }^{25}$ The initially established floor and ceiling prices are $£ 730$ and $£ 880$, respectively, a range of $20 \%$ measured from bottom (art. VI, para. 2).

${ }^{30}$ The Textile Agreement, for its part, infra note 46 , it may be noted, provides for gradually increasing quotas for low-cost producers.

${ }^{37}$ E.g., Raymond Vernon: The "incipient and completed agreements (so far as known) have reflected little in the way of guiding principle or philosophy. . . . Commodity agreements . . . have largely represented producers' proposals for the solution of producers' problems and little more. ..." The wheat agreement "contributes little to solving the basic wheat problem of excess production or under-consumption." The sugar agreement contains "little . . . which . . . contributes to the withdrawal of land from economic, high-cost sugar beet production. . . . The tin agreement follows a third pattern and the olive oil agreement is likely to pursue even a fourth. The point is, of course, that arrangements so negotiated have taken on whatever form a short-run pragmatism dictates. . . " RAYMOND VerNoN, Organizing for World Trade, Int'z Conc. PAMphiet No. 505, at 163, I80-81 (1955). 
and a hope of increased consumption. Nonetheless, expectation of amelioration of underlying maladjustment was evidently in the background of the negotiation of at least the two newest agreements; ${ }^{38}$ and several provisions may be found in the primary commodity agreements that look to the cutting back of market-disturbing overproduction or high-cost production. For sugar, examples of such provisions are article 3 (on prejudicial subsidies), and articles 4 and ro (on production controls). It may be said, at least, that mutually understood trade targets are set which enable governments to go about arresting the expansion of unneeded production and cutting back excess production with better confidence. ${ }^{39}$ The point of balance, as between efficiency and inefficiency, is struck in the bargaining over these targets.

The remaining substantive requirements, (e), (f), and (l), appear to be observed at least presumptively in all four agreements, in the opinion of the participants. This collectively represents in each case a heavy weight of opinion, even though the agreements do not on their face afford a conclusive objective answer-if any such answer is indeed susceptible of being established, given the weighting of imponderables and the diverging equities involved. ${ }^{40}$

The most reliable safeguards, undoubtedly, are the procedural ones, including the Study Group preparatory procedure. These are calculated to assure full opportunity for the play of the vigilance of affected countries whose varying consumer and producer interests do not coincide, backed by the knowledge bred of experience that substantial dissent and non-cooperation is likely to hamper, if not wreck, the ultimate success of such agreements on most commodities in the long run. ${ }^{\mathbf{4 1}}$ It is through their operation, rather than the possibly self-centered opinions of one clique or other of producers or consumers, that substantive fidelity may be expected to be most sedulously policed. The consensus needed for agreement implies a collective judgment that elusively-defined substantive desiderata have been taken into account so far as possible.

All the primary commodity agreements observe (d), (i), and (j). The system of allotting the exporters and importers each 1,000 votes, with agreed weights by country roughly proportionate to each country's significance in the trade, is common to all. ${ }^{12}$ They all likewise evince compliance with the remaining procedural directives, (a)-(c)

${ }^{88}$ Coffee, see Bilder, The International Coffee Agreement, supra, at 328; textiles, see infra, at 406 .

${ }^{80}$ Though the Wheat Agreement, for example, contains the proviso, "Nothing in this Article shall prejudice the complete liberty of action of any . . . country in the determination and administration of its internal agricultural and price policies" (art. 23, para. 3), United States wheat acreage has been materially reduced in the period since the agreement series was inaugurated in 1949 . Average acreage harvested I946-1950 was 70.3 million; 195I-1955, 60.5 million; and down to 50 million in 1956-1960. Statistical Aestract of the United States 65I (1962).

"Further to "(e)," see infra.

¿1 The classic example, of course, was the ill-starred Stevenson Plan of the 1920's for the shoring up of rubber prices by limiting output and exports in British-controlled areas. The result was stimulation of production in nonparticipating areas (e.g., Dutch Indonesia), and of the development of a reclaimedrubber industry and a search for substitutes in the United States (the principal consumer).

${ }^{2}$ The textile agreement, infra, at 406 , does not observe (d), for reasons peculiar to its subject-matter; but the other procedural points are observed by it. 
and $(k)$, when allowance is made for the fact that the Organization envisaged by chapter VI has never materialized."3 There are no "Members"; there also is no "Organization" to call conferences, ${ }^{44}$ or to act as custodian, supervisor ${ }^{45}$ and arbiter of disputes unresolved by a Commodity Council. But, in substitution, universal participation is sought, and various ways devised for an alternative to Organization surveillance. It has been seen above how the GATT, for example, implicitly fills the overseer role for GATT members; and it will be shown below that the textile arrangement is explicitly meshed into the GATT. The Sugar and Wheat agreements, for their part, expressly subordinate themselves to any requirements that may be laid down by the United Nations, operating through its appropriate organs or specialized agencies (paragraph 2 of articles 39 and 34, respectively). Additional procedural provisions also tend to safeguard against the perpetuation of inequities and arbitrary rigidities. The case of the Coffee Agreement is discussed in greater detail elsewhere in this issue. ${ }^{45 a}$ The Wheat Agreement provides for an annual (but noncommittal) review of the world wheat situation (article 23); for quota relief (articles 9 and $\mathrm{r2}$ ) and adjustments (article 2I), in certain contingencies; for amendment (article 36 , paragraphs 2 et seq); and for the termination of the agreement (and thus its reopening unless prolonged) at the end of three years, in lieu of the five years characteristic of other agreements (article 36 , paragraph I). The Sugar Agreement provides (as does Coffee) for a thorough review at the end of three years with a view to any modification of its terms as might appear to be indicated (article 42, paragraph 2), as well as for other possibilities of amendment and relief (articles 43 and 44 ).

"GATT is a partial, but juridically incomplete substitute. It (I) lacks appropriate status as an organization, (2) deals with only a portion of the field covered by the Charter, and (3) has a membership which, despite its large number and preponderant trade importance, is short of the universality contemplated by the Charter's craftsmen. The Interim Co-ordinating Committee for International Commodity Arrangements (ICCICA) functions also in partial substitution, as a coordinator and synthesizer of information; it prepares a Review of International Commodity Problems [hereinafter cited as Review], issued annually since 1948 under United Nations (ECOSOC) auspices. This publication inter alia reviews the activities of the various commodity Study Groups which serve as media for systematic consultation and for preparing the way, where indicated, for negotiation of commodity agreements. In I949, current "intergovernmental consultation and action" was reported on the following: wheat, tea, sugar, cotton, rubber, tin, and wool; in $196 \mathrm{I}$, on the same commodities less tea, plus butter, cocoa, coconut products, coffee, grains, hard fibres, jute, lead and zinc, olive oil, petroleum, rice, spices, and tungsten. I 1962 REview 13-4I (U.N. Doc. No. E/3614). While the Committee is cautious in criticism, it has invited attention to the Tea Agreement's lapse regarding consumer representation; Observations Regarding Inter-Governmental Consultation and Action on Commodity Problems, I949 REview I4 (U.N. PUB. SAIES No. 1950.II.D.2); 1950 Review 5 (U.N. Doc. No. E/I907) (U.N. Pub. SAIES No. r95r.II.D2.); and the failure of opportunity for non-participants to present their views on the occasion of the first renewal of the Wheat Agreement of I949. I953 Review 8 (U.N. Doc. No. E/2578) (U.N. Pub. SAles No. 1954.II.D.3). It has stressed the essentiality of consumer-interest representation (id. at 6 , and in various others) and for full publicity and broad participation at all stages (repeatedly); it has commented favorably on features in the agreements that provide flexibility and a degree of price competition (rg6r Review I6, and 1962 Review 8-9) and on the provisions made in the Coffee Agreement (I962 Review 7 ) consistent with its recommendation for attention to alternative employment of coffee-growing resources (I960 Review para. 13).

"The United Nations, or, in the case of textiles, the GATT, is used as convoking agency.

"Art. 65(3) of the Havana Charter, for example, provides that agreements failing in substantial conformity with the Chapter, in the opinion of the Organization, have to be revised or terminated.

4sa Bilder, The International Coffee Agreement, 1962, supra, at 328. 
Thus, making allowance for the non-existence of the Organization and for the ambiguities in the substantive elements of the chapter VI guidelines, it can be said that its criteria and general design have tended to be respected in practice.

\section{V}

\section{The Cotron Textile Agreement}

The long-term Cotton Textile Arrangement, ${ }^{46}$ concluded at Geneva, February 9 , I962, and effective for a period of five years beginning October I, I962, is a special case. As it does not treat of a "primary commodity," but rather of a category of manufactures, it does not on its face come within the terms of the GATT reservation expressly permitting agreements based on the principles of chapter VI of the Havana Charter. That chapter is in its basic intendment confined to "primary commodities." Article 56 of the chapter, it is true, allows also for agreements on "Related Commodities," but these are so limitatively described as evidently to exclude products having the characteristics and the production and trade circumstances of cotton textiles. A "related" commodity is one that "in exceptional circumstances" may be determined not to "fall precisely" within the definition of a "primary" commodity 47 but that nonetheless is suffering the trigger conditions set forth in article 62 , to wit: either

(a) An actual or prospective "burdensome surplus ... which, in the absence of specific governmental action, would cause serious hardship to producers [notably small producers] ... because characteristically ... a substantial reduction in price does not readily lead to a significant increase in consumption or to a significant decrease in production;

or

(b) widespread unemployment or under-employment ... arising out of difficulties of the kind referred to in article 55 [tendency towards persistent disequilibrium between production and consumption, the accumulation of burdensome stocks and pronounced fluctuations in prices] ... (and) characteristically in the case of the industry concerned, a substantial reduction in price does not lead to a significant increase in consumption but to a reduction of employment ... (in) areas ... (that) do not afford alternative employment opportunities. ...

While the cotton textile industry, as concerns production and world trade, is afflicted in ways that smack of various passages in this recitation, its problem conditions are

${ }^{40}$ Text reproduced in 46 Dep'T State Bull. 43r-34 (Ig62), T.I.A.S. No. 5240. The nineteen signatories are Australia, Austria, Canada, Denmark, India, Japan, Norway, Pakistan, Portugal, Spain, Sweden, United Kingdom (representing also Hong Kong), United States, and the six member states of the European Economic Community (France, West Germany, Italy, Belgium, Luxembourg, and The Netherlands).

${ }^{47}$ The introductory article (art. 55) of chapter VI, which sets its orientation, is entitled "Difficulties Relating to Primary Commodities," and the succeeding article (art. 56) defines the subject matter as follows: "I. For the purposes of this Charter, the term 'primary commodity' means any product of farm, forest or fishery, or any mineral, in its natural form or which has undergone such processing as is customarily required to prepare it for marketing in substantial volume in international trade." (Emphasis added.) 
not coincident with their general thrust. ${ }^{48}$ The textile agreement was provoked by rising competitive pressures from the low-wage producers of Asia upon the domestic industry of already industrialized countries of the West; and it was not the sheltering of established manufacturers in highly-developed nations that the genesis and drafting of article VI had in contemplation.

The difficulty of squaring the Long-Term Arrangement with chapter VI is, moreover, compounded by the implications of a crucial feature of the latter's procedural prescriptions. Its article 64 on "Administration of Commodity Control Agreements," together with article $6_{3}(\mathrm{~b})$ incorporated by reference, visualizes the participants as falling into two adversary groups of equal voice, those classed either as mainly importers or as mainly exporters, with respect to their international commercial interests. $^{49}$ But in the administrative set-up provided in the Long-Term Arrangement there has been no division into two groups with co-equal weight, "importers" and "exporters," such as occurs, conformably with the scheme of article VI, in the primarycommodity agreements discussed above. The difficulties giving rise to the negotiation of the cotton-textile arrangement have been largely those experienced by importing countries; ${ }^{\mathbf{0}}$ and these importing countries are at the same time mostly also substantial exporters, ${ }^{51}$ although it was not to stabilize or otherwise assist the export

"S The first of the Preparatory Committee drafts (art. 52(3), "London" draft) had allowed for an Organization finding, in exceptional circumstances, that a commodity agreement could cover manufactured goods. But this opening was whittled back, in subsequent stages of the draft, to the "related commodity" concept, which is asserted to envisage merely "certain marginal products, such as butter and cheese, which come close to satisfying the definition but fail to do so 'precisely,' because they have been subjected to more than an initial stage of processing." Clair Wilcox, A CharTer for WorLd TRADE 120 (1949). For statistical purposes, the Commission on International Commodity Trade currently includes the following semi-manufactured or processed products in its list of primary commodities: butter, cheese, rayon, synthetic rubber, wood pulp, and refined petroleum. Commodity Survey for 1959 and 1960, respectively, U.N. Doc. Nos. ST/ECA/62, at $x_{4} ;$ and ST/ECA/67, at 47. Proposals have been made to enlarge the concept of "commodity" to include "products where processing had been carried to an advanced stage" as well as "semi-finished or finished products" (BISD 97 (Ioth Supp. 1962)); but so far these remain unadopted proposals.

"Chapter VI, article $\sigma_{3}(\mathrm{~b})$ recognizes the possibility that some country might "not fall precisely" into either of these two classes; but in all actual agreements where the division into the two classes is made, there appears to be no case of a country which does not fall fully into either one or the otherexcept in the contingency provided for in article 69 (namely, a metropole with dependent territories, in which the former goes in one group and the latter in the other).

${ }^{50}$ Characteristically, it is the exporter-countries which actuate commodity control agreements, rather than countries requiring protection of their domestic producers from foreign competitors. The aim of chapter VI was to convert what had historically tended to be an exporter price-maintenance consortium into a joint importer-exporter cooperative, in order to assure a sympathetic regard for consumer interests. In this connection, recent expert opinion (ICCICA) on the prospects for a more general use of the commodity-agreement device emphasizes that ways need to be found for offering "effective incentives for the participation of importing countries," in order to overcome the latter's resistance to accepting controls designed to hold up the prices they must pay for what they buy. I96r REview 30 .

${ }^{51}$ In fact, many of them appear to export cven more cotton fabrics (SITC \#652) than they import. Exports in 1960 exceeded imports in value by the following approximate percentages: in the United States, 56\%; Belgium-Luxembourg, $120 \%$ plus; Germany, 40\% plus; Italy $330 \%$ plus; the Netherlands $90 \%$ plus. In two other cases, where cotton-content goods are not segregated from the master fabrics class, the export excess of the overall group was Denmark, 20\%; France, 50\% plus. The United Kingdom, Canada, and Austria, on the other hand, are not importers. UNITED Nations YeArBOOK OF INTERNatjonal Trade Statistics (I960). Two other categories covered by the Arrangement, cotton yarns and apparel, are not generally segregated in this source book so as to permit comparison. 
aspect of their interest that they were led to enter the Arrangement. ${ }^{62}$

The question of compliance with GATT, however, is not exhausted by the test of chapter VI. GATT article XX(h), as now amended, provides also for the permissibility of commodity agreements not based on the principles of chapter VI: to wit, as noted above, "any inter-governmental commodity agreement which conforms to criteria submitted to the CONTRACTING PARTIES and not disapproved by them or which is itself so submitted and not so disapproved." Hence, so long as the CONTRACTING PARTIES have the opportunity ${ }^{53}$ to disown the Arrangement, and do not choose to do so, ${ }^{54}$ the Arrangement is automatically conformable with GATT, assuming that it can indeed be considered a "commodity" agreement of one sort or other.

But whether the Long-Range Cotton Textile Arrangement is, properly speaking, a commodity agreement at all, is open to doubt. If it is not, then the determination of its conformity with GATT would rest on grounds other than the article $\mathrm{XX}(\mathrm{h})$ reservation. If it be not a "commodity agreement," there appears to be no explicit provision in the General Agreement covering it, although prima facie its terms raise the same issue of compatibility with the fundamental trading rules of GATT that are described in the first section of this paper. ${ }^{55}$ That it may, indeed, be considered a unique contrivance of first impression, differing from a commodity agreement, is suggested by the fact that without professing to be a "commodity" agreement, it is conceived as being a "special" and temporary "practical measure" of "international cooperation" which will "assist in any adjustment that may be required by changes in the pattern of world trade in cotton textiles" (article $\mathrm{I}$ ); and that it avowedly deals with the particular phenomenon of "market disruption," a concept not so far figuring in commodity-agreement rationale and parlance.

The existence of a special "market disruption" problem" calling for special

${ }^{\text {Ea }}$ From the viewpoint of the United States Government, which took a leading role in bringing it to pass, the Arrangement is deemed to realize a step in President Kennedy's seven-point program for the relief of the American cotton textile industry, President Announces Program to Aid U.S. Textile Industry, 44 Dep't State Bull. 825 (196r), a fact to which attention was invited in the White House press release of Feb. 15, 1962, announcing the conclusion of the Arrangement. GATT Members Conclude LongTerm Cotton Textile Arrangement, 46 Dep't State BuLl. 430 (1962).

${ }_{B s}$ The short-term arrangement of July $2 x$, I96I, T.I.A.S. No. 4884 , out of which grew the present long-term one, was formally krought to the notice of the Contracting Parties through having been published as one of the "Decisions, Declarations, Etc." carried in the BISD 18 (roth Supp. 1962). The same has been done for the Long-Term Arrangement. BISD 25 (IIth Supp. 1963).

to Considering that all affected GATT members so desiring had opportunity to participate, it is extremely unlikely that the action of the influential members choosing to participate would be challenged by a majority of the Contracting Parties.

Es That is, the Arrangement allows administered restraints in the form of quotas on the movement of the product in international trade; and that these may provoke charges of discrimination and prejudicial exclusion is illustrated by current press accounts (February I963) of Japanese and Philippine complaints about United States actions under the Arrangement.

${ }^{80} \mathrm{So}$ in the "Noting" recital of the Preamble, and in Article ro and Annex $\mathrm{C}$, the latter being a definition of "market disruption" approved by the GATT Contracting Partics.

${ }^{57}$ The GATT Working Party established to study the problem and recommend a Decision found that the majority of examples of alleged market disruption related precisely to the textile and clothing industries. BISD rog ( 9 th Supp. $196 \mathrm{r}$ ). 
attention has been recognized in a "Decision" of the CONTRACTING PARTIES, in which the said Parties "agree" that "constructive solutions" should be sought, and to that end establish a Committee on Avoidance of Market Disruption to keep the problem under study, facilitate consultation among interested parties, and suggest "multilaterally acceptable solutions." The Arrangement, having been negotiated and consummated under GATT auspices (or, more exactly, with the help of the good offices and facilities of the GAT'T), and with participation of all its interested members, presumably constitutes such a "constructive" or "multilaterally acceptable" solution of a "market-disruption problem" in the eyes of GATT. The Arrangement further is meshed into the GATT by having its administrative organ made identical with the "Cotton Textiles Committee" created by the CONTRACTING PARTIES at their nineteenth session (article 8); and by the fact that the participants in the Arrangement reserve all "their rights and obligations under the General Agreement on Tariffs and Trade" (article I). ${ }^{59}$ Such reservation, of course, ipso facto ensures consistency with the GATT. Thereby, what would be yielded by the presence of article $\mathrm{XX}(\mathrm{h})$ in the General Agreement, were it treated without more as a "commodity" agreement, is not yielded. Furthermore, in keeping with the GATT objective of expanding international trade, the Arrangement also (a) exacts a promise that "those participating countries still maintaining restrictions inconsistent with the provisions of the GATT . . . agree to relax those restrictions progressively each year with a view to their elimination as soon as possible,"60 and (b) for the rest, provides for an annual increase of at least five per cent in the size of the import quotas that may be resorted to under the Arrangement by any participant (article 3, paragraph $I$, and Annex B).

The textile Arrangement, whatever its genus, shares with the commodity agreements on primary products a common denominator of approach. That is, they all alike are open covenants, openly arrived at, and openly administered; they endeavor to reconcile all interests in a widely recognized problem situation, with full participation of all desiring to be represented and to take part; they make the responsibility a public, supervised one; they endeavor to guard against abuse; and with varying degrees of conviction they, for the most part, hopefully look toward an ultimate normalization of trade in the product coyered, upon correction of the maladjustments giving rise to the need for exceptional regulation. It was for some such responsible facing-up to an acknowledged special need, which defies effective fulfillment under the classical ground-rules delineated in principle as the core of the GATT, that chapter VI was designed to provide.

${ }^{88}$ Decision dated Nov. I9, I960. BISD 26 (9th Supp. I96r).

${ }^{\circ}$ Including, particularly, their rights of recourse under GATT art. XXIII (art. 7, para. 3 ).

${ }^{\circ}$ This has reference to stringent import restrictions heretofore maintained by several of the EEC states and others against textiles from low-wage countries notwithstanding their GATT commitments. So, the EEC has now announced a staggered $88 \%$ relaxation of such restrictions. N.Y. Times, Sept. 28, I962, p. 45, col. 4. On the other hand, the Arrangement is designed to obviate the irregular expedient of "voluntary" export controls by Japan that had previously been resorted to in order to head off unilateral United States import restrictions. 


\section{VI}

\section{Obligations Towards Non-Members}

To this point, the examination has been in terms of the GATT. But GATT is by no means universal in its membership; many nations have not joined. ${ }^{01}$ If, as may well happen, such countries choose not to participate in a given commodity agreement, ${ }^{62}$ the question of their legal rights is not disposed of by the agreement's acceptability to GATT. Their interests can quite conceivably be materially affected, for it is normal that such agreements contain provisions designed to safeguard against the possibility that outsiders, who have not accepted the limitations of the agreement, might gain an advantage over one or more of the participants and frustrate the success of the endeavor. In such eventuality, the instance in which a non-GATT country might have a legal claim against an agreement-participant would be that in which there existed a contractual relationship between the two (e.g., a bilateral commercial treaty or trade agreement) which the participant would have to violate in order to carry out its commodity-agreement obligations. Whether such a claim might arise would depend upon the terms of the contractual relationship, in light of the treatment being applied by a participant to the commerce of the non-GATT country.

Reconciliation of the obligations of a bilateral treaty with those of a commodity agreement is eased, in the typical case, by the fact that such treaties do not generally purport to forbid quantitative restrictions as such. In this, their aim is more modest than that of the multilateral GATT; they tend to confine their prescriptions to con. tingently providing that if such restrictions are applied they shall be administered according to equitable criteria, for example: ${ }^{63}$

Neither Party shall impose any prohibition or restriction on the importation of any product of the other Party, or on the exportation of any article to the territories of the other Party, that:

(b) ... does not apply equally to the importation of the like product of, or the exportation of the like article to, any third country; or

(c) if a quantitative regulation involving allotment to any third country, with respect to an article in which such other Party has an important interest, fails to afford to the commerce of such other Party a share proportionate to the amount by quantity or value supplied by or to such other Party during a previous representative period, due consideration being given to any special factors affecting the trade in the article.

${ }^{01}$ E.g., U.S.S.R., both Chinas, Venezuela, and Mexico. The non-member nations, though in a majority by number, account for only a minor fraction of world trade outside the bloc.

${ }^{62}$ In fact, however, they are likely to participate if they have an interest in the product: e.g., U.S.S.R. is party to the Wheat, Tin, and Sugar agreements.

${ }^{8}$ Art. XII, para. 2, of the I950 Treaty of Friendship, Commerce and Navigation with Ireland, T.I.A.S. No. 2155. Similar provisions typically occur in the other treaties cited infra note 74. Compare GATT art. XIII. 
Article 60, paragraph I(c), of chapter VI, it will be recalled, requires that nonparticipants be accorded an "equitable treatment." Commodity agreement quota schemes normally involve allocations calculated according to some recent statistical base period, as a method of arriving at an appropriate distribution among the various participants. The question for the outsider, then, is (I) whether his quota is calculated the same way; ${ }^{64}$ and (2) even so, whether allocation is really based on an acceptable previous "representative period" in the particular facts and circumstances of the trade flow between the two countries concerned. Merely to use automatically, for example, the previous twelve-month period (with a three-month lag), as in the Long-Term Cotton Textile Arrangement (Annex B), even though agreeable to the participants, does not necessarily meet the test. For a variety of reasons, the last year may very well not be "representative" for the particular country involved, nor take account of the trend of its trade and its developing prospects. ${ }^{65}$ In this connection, it is related elsewhere in this issue how it was necessary to negotiate adjustments for several of the producers participating in the Coffee Agreement, owing to the unsuitability for them of the formula used as general basis for calculation (itself, in turn, a subject of considerable jockeying for position).

Whether there arises a legal issue depends, then, on whether the commodity agreement obliges participants to accord non-participants a quota that falls short of meeting the test, and whether the participant actually imposes an inadequate quota in a particular instance. For present purposes, attention may be confined to the first of these questions: i.e., the posing of a conflict in obligation. The commodity agreements vary in the extent to which they impose obligations that might conceivably require participants to take measures in conflict with their oustanding commitments to outsiders. However, it would appear that the primary-commodity agreements have been so devised as probably to obviate necessitous conflicts.

The Coffee Agreement provides (article 45), "in order to prevent non-Member exporting countries from increasing their exports at the expense of Members," that until ninety-five per cent of the world exports ${ }^{66}$ come under the Agreement, each

\footnotetext{
'It may be noted that art. 60 , para. I (c), allows the possibility of a smaller quota for non-participants, as compared with participant quotas, through the proviso "due consideration being given in each case to policies adopted by non-participants in relation to obligations assumed and advantages conferred under the agreement."

${ }^{A 5}$ A Philippine government spokesman is reported to have assailed as "unjust and unfair" the import restrictions imposed by the United States on Philippine textile products (AP dispatch, Manila, Durham Morning Herald, Fcb. Io, I963, p. 9A, col. I). Whether violation of the United States-Philippine trade agreement (the Philippines being party to neither GATT nor the textile arrangement) has becn alleged is not stated. That agreement (as revised in I955, T.I.A.S. No. 3348) contains a provision on quantitative restrictions like that quoted supra at note 63 (art. III, para. I); and statistics show that total Philippine textile cxports, and hence their future prospects, are growing faster than those of its two neighboring competitors: for the period $1957-1960$, an increase in value of $22.5 \%$, as against $12.5 \%$ for Japan and $2 \%$ for Hong Kong, an "additional ability to export" being among the "special factors" to be considered. (Havana Charter, Annex P). On the other hand, however, the same article III contains an escapeclause that permits quotas based on a previous 12 -month history, if imposed to protect domestic industry against serious injury or threat thereof.

${ }^{\circ 0}$ This percentage can be raised by decision of the governing Council.
} 
importing Member shall limit its imports from non-Members ${ }^{07}$ to a quantity not exceeding the average it took from such non-Members "as a group" over the preceding three years. "As a group" is a phrase which would give an importer latitude to adjust for individual, bilateral commitments in case the three-year period (which cuts off prior to date of Agreement, and does not provide for a "moving average") should not prove sufficiently "representative" in a given case covered by such commitment. There is, in addition, a savings clause for outstanding bilateral commitments Members may have, provided the Member concerned does what is possible to minimize conflicts, and takes steps to bring such commitments into harmony with its Agreement obligations (article 45, paragraph 7).

The Sugar Agreement provides that imports from non-participants "as a group" shall be limited to those in "any one of the three calendar years 1951, 1952, I953" (article 7, paragraph I); but further, that any participant which considers that it cannot carry out this obligation is entitled to such release as may be necessary (article 7, paragraph 3). The history of commodity-agreement regulation of the sugar trade is sufficiently long ${ }^{68}$ (as also with Wheat, for that matter) that participants will presumably have had opportunity generally to conform any of their independent bilateral commitments by now, to the extent necessary. ${ }^{69}$ The Wheat Agreement, for its part, essentially provides that importing participants take an agreed percentage of their commercial purchases of wheat from the exporting members (within a prescribed price range), such percentage varying from sixty to ninety per cent depending on the country (Annex A). ${ }^{70}$ Considering the very small fraction of world wheat exports not under this Agreement, ${ }^{71}$ the importers have presumably allowed themselves ample latitude, and more, to take care of any extra-Agreement wheat imports to which they might be bilaterally committed. There are also various provisions for relief from and adjustment of agreement commitments (notably, in part III). The Tin Agreement, finally, does not provide for market quotas, but only for a "buffer stock," reinforced where necessary by "global" export quotas, ${ }^{72}$ for price maintenance purposes. Both features are non-discriminatory; all willing and able purchasers

${ }^{67}$ Original non-signatories, it may be noted, account for considerably more than the applicable $5 \%$ of world exports (e.g., Ecuador, Ethiopia, India, Indonesia, Nicaragua, and Portugal together accounting for over II \% .

${ }^{68}$ The current Agreement (1958) replaces one of 1953 , as amended in 1956.

${ }^{60}$ There are also rights to maintain earlier reservations, and the possibility of new ones, to cover special contingencies (art. 45).

${ }^{70}$ Except Vatican City, 100\%, and figures of $30 \%$ to $50 \%$ for Brazil, Poland, and the United Arab Republic.

${ }^{71}$ Export figures in the 1959 and 1960 volumes of the U.N. Commodity Trade Statistics show that significant total wheat exports from non-signatories in those years (Greece, Turkey, Ireland, and Yugoslavia) were less even than the tonnage of one of the least of the exporter participants (Italy, with only trade to warrant $x \%$ of the voting weight).

${ }_{72}$ Producers may be required to impose specified export quotas when the governing Council declares a three-month "control period" (in principle, when the buffer stock reaches ro,000 tons). In the sixteen quarters of the period I957-r960, there were eleven such "control periods" declared. International Tin Council, ig6o Statistical Yearbook it. 
are apparently treated on an equal commercial footing within the established price range. ${ }^{73}$

The possibility of conflicts is attenuated also by the character of the bilateral commercial treaties and trade agreements to which countries are typically committed in the post-World War II era. The United States, for example, has followed a policy in its postwar commercial treaty negotiations of including a proviso reserving measures it might take in conformity with the GATT, as follows: ${ }^{74}$

The provisions of the present Treaty relating to the treatment of goods shall not preclude action by either Party which is required or specifically permitted by the General Agreement on Tariffs and Trade ... during such time as such Party is a contracting party to the General Agreement. ...

In addition, it has tidied up many of its commitments by suspending, terminating, or renegotiating them. ${ }^{75}$ Other countries have generally tended to refrain from concluding tight long-term bilateral treaty commitments affecting commercial relations, at least in ways calculated to interfere with their entering upon commodity agreements. $^{78}$ Bilateral commercial agreements, the frequency and scope of which has fallen off (except by or vis-à-vis state-trading economies) in recent years since the restoration of currency convertibility and the extensive dismantling of administrative trade controls and the growth of the GATT, have tended to be short-term or quickly terminable affairs with an ample cushion in the form of limited or guarded commitments or of explicit or implicit escape clauses. ${ }^{77}$

In sum, leaving aside a possible question regarding the textile arrangement and the question of non-obligatory measures that a participant might take, it would presumptively appear that the control agreements now in force are probably calcu-

${ }^{78}$ Articles IX and XI.

"Article XX, para. 2, of the Treaty with Ireland, supra note 63. Similarly in post-War treaties with other non-GATT countries: China, 1946 , attached exchange of notes, T.I.A.S. No. I87x; Ethiopia, I95I, art. XII, para. 6, T.I.A.S. No. 2864; Iran, I955, art. VIII, para. 6, T.I.A.S. No. 3853; Korea, I956, art. XXI, para. 3, T.I.A.S. No. 3947; Viet-Nam, I96I, art. IX, para. 6, T.I.A.S. No. 4890; but not in the Trade Agreement with the Philippines, supra note 65 , a unique instrument providing inter alia for the phasing out of preferences that are no longer warranted in view of Philippine acquisition of independence in 1946. The primary commodity agreements would arguably be "specifically permitted," within the terms of the above-quoted proviso; but quaere, would the textile agreement?

${ }^{75}$ However, there remain in force, without a recorded GATT reservation, pre-War engagements with non-GATT countries requiring unconditional most-favored-nation treatment and non-discrimination in quantitative regulations: Honduras, trade agreement of 1935, arts. VI, para. I, and IX (49 Stat. $385 \mathrm{I}$ ), and behind it the r927 commercial treaty (T.S. No. 764); Liberia, treaty of I938, arts. VIII and IX (54 Stat. 1739); Siam (Thailand), treaty of 1937, arts. 3 and 8 (T.S. No. 940). These are all terminable on notice of six or twelve months. Thailand is signatory to the Tin Agreement, and Honduras to the one on coffee. But Liberia and Honduras both have minor export interests, sufficient to be recorded in general statistical summaries, variously in agreements to which they are not parties: cotton fabrics, sugar, coffee, and wheat (and flour), amounting together to about $4 \%$ and $8 \%$, respectively, of their total 1960 exports.

${ }^{70} \mathrm{~A}$ most-favored-nation clause might typically be included. But this clause has only very imprecise bearing on the question of size of quotas, a subject on which a meaningful commitment requires a special provision, such as that quoted supra note 63 .

${ }^{77}$ For a random example, the Franco-Greek trade agreement of 1952 and para. $I$ of its annexed protocol, 187 U.N.T.S. 175, as extended, 225 U.N.T.S. 289. 
lated to pose few, if any, significant conflicts with other outstanding commercial engagements of the participants. This follows from the GATT, the extent of participation, the margins of tolerance in the agreements, and the general character of extant bilateral independent commitments.

\section{Conclusion}

In conclusion, two observations seem to be called for regarding commodity agreements in the years since World War II. First, very few such agreements have come into being. Secondly, those made have tended to observe the principles enunciated in chapter VI of the Havana Charter to a notable degree. The first is doubtlessly related in considerable measure to the second. Chapter VI, in seeking to regularize such agreements, stressed above all an equal voice for importing countries, as a safeguard to consumers against producer-cartel exactions; and the difficulty of reconciling producer and consumer interests has been a major brake upon successful negotiation of such agreements.

No legal obligation has lain upon states to follow chapter VI, for the Havana Charter was stillborn. It never became law for anyone. It has only a hortatory status by virtue of ECOSOC resolutions, and a permissive standing for GATT members. The absence of the surveillant Organization contemplated by the Charter, as a key to securing the integrity of its operative principles, moreover, has been a practical impediment to fulfillment of its objectives. Nevertheless, for whatever reason, the chapter has evidently acquired a respectable authority as a code of behavior to be followed; and ways have been found, through the play of a collaborative spirit, through the informational and coordinating role of the ICCICA, and through the growth of the GATT as international commercial-policy standardbearer, for substantially supplying the organizational deficiency.

The tendency of states, on the whole, to live up to the Havana Charter has produced agreements that, in the informed opinion of the ICCICA, have "in practice ... assisted participating consumer countries."78 With the experience of the last decade and a half as assurance, and with the recent indications of a more sympathetic attitude toward the commodity-agreement device on the part of the United States ${ }^{7 \theta}$ (the

${ }^{78}$ x96x Review 22. But $o f$. the opinion of Dr. John J. Schanz, The United States and a Post-War Tin Control Agreement (unpublished dissertation in Pennsylvania State University Library, 1954) that, in the particular instance of tin, United States participation in the Tin Agreement would not be to the economic advantage of United States consumers, though desirable on other grounds. Schanz, supra, at 247.

${ }^{70}$ The 1962 Coffee Agreement is the first involving a commodity not produced in the United States to which the United States has been party. Current policy is set forth by Deputy Assistant Secretary of State Michael Blumenthal in his address, Commodity Stabilization and Economic Development in Africa, 47 Dep'T STATE Bulz. 6I6, 6I9 (I962), wherein, however, caveats are expressed about the utility of commodity agreements as a cure-all and the essentiality of their being employed in conjunction with corrective resource-utilization measures, a theme marking also his earlier statement at the roth Session of the United Nations Commission on International Commodity Trade. See Blumenthal, International Commodity Problems, 46 Dep'T State BuLL. 997 (1962). President Kennedy has recently declared the willingness of the United States "to move ahead on agreements stabilizing the prices of other 
world's principal importer and consumer of primary products), the future may well see an increased resort to such agreements. If so, the momentum of the line of precedents now built up should carry the further case-by-case crystallization of a recognized law of commodity agreements along constructive channels. The Charter is dead, but its spirit seems fated to live on anyhow in a code of international trade practices such as it sought to create.

commodities" (remarks upon convening of the Presidents' Conference, San Jose, Costa Rica, as released by the Office of the White House Press Secretary, March I8, I963, p. 3). 